\title{
Tillage and rice-wheat cropping systems influences on soil physical properties: Water balance and wheat yield under irrigated conditions
}

\author{
R. K. Naresh ${ }^{1 *}$, S. S. Dhaliwal ${ }^{2}$, D. Kumar ${ }^{3}$, S. S.Tomar ${ }^{1}$, A. K. Misra ${ }^{4}$, S. P. Singh ${ }^{5}$, P.Kumar ${ }^{1}$, \\ V. Kumar ${ }^{1}$ and R. K.Gupta ${ }^{6}$ \\ ${ }^{1}$ Department of Agronomy, Sardar Vallabhbhai Patel University of Agriculture and Technology, \\ Meerut-250110 (U.P.), India. \\ ${ }^{5}$ Department of Soil Science, Sardar Vallabhbhai Patel University of Agriculture and Technology, \\ Meerut-250110 (U.P.), India. \\ ${ }^{2}$ Department of Soil Science, Punjab Agricultural University, Ludhiana (Pb.), India. \\ ${ }^{3}$ Department of Agronomy, Punjab Agricultural University, Ludhiana (Pb.), India. \\ ${ }^{4}$ K.V.K.Moradabad, Sardar Vallabhbhai Patel University of Agriculture and Technology, Meerut-250110 (U.P.), India. \\ ${ }^{6}$ Research Station Developments, Borlaug Institute for South Asia, CIMMYT New Delhi, India.
}

Received 25 October, 2013; Accepted 16 June, 2014

\begin{abstract}
Challenge of increasing food production in the next 20 years to match population growth is daunting and warrants improvement in the quality of natural resources for growing more food from marginal and degraded lands.Adopting a better tillage system does not only improve the soil health and crop productivity but also improves the environment. A field experiment was conducted to investigate the effects of tillage and irrigation management on wheat (Triticum aestivum L.) production in a post-rice (Oryza sativa L.) management system on sandy loam soil for 2009 to 2010 and 2011 to 2012. Four irrigation levels ( $I_{1}$ :irrigation at crown root initiation (CRI); $I_{2}$ :irrigation at CRI+jointing; $I_{3}$ :irrigation at CRI+ jointing+ flowering; $\mathrm{I}_{4}$ :irrigation at CRI+ jointing+flowering+dough) stages and three tillage systems (ZT: zero tillage;BPW:bed planted wheat and CT:conventional tillage) were tested. Zero tillage compared to $C T$, resulted in higher bulk density $\left(1.60 \mathrm{vs} 1.49 \mathrm{Mg} \cdot \mathrm{m}^{-3}\right)$, lower total porosity $(49.3 \mathrm{vs}$ $53.7 \%)$, higher penetration resistance ( $1.50 \mathrm{vs} 1.24 \mathrm{MPa})$, and lower steady state infiltration rate ( $0.18 \mathrm{vs}$ $0.38 \mathrm{~mm} \cdot \mathrm{h}^{-1}$ ) in the surface 0 to $15 \mathrm{~cm}$ soil layer.Irrigation levels significantly affected crop water use, wheat yield, and water use efficiency (WUE). Aggregates $<25 \mathrm{~mm} \mathrm{ZT}$ was significantly higher $(4.4 \%)$, than CT and BPW methods (3.2 and 3.4\%, respectively. Grain yield declined by $20.5,11.7$ and $7.7 \%$ of 14 $\left(4.57 \mathrm{Mg} \cdot \mathrm{ha}^{-1}\right)$ with $I_{1}, I_{2}$ and $I_{3}$ treatments. Average values of WUE were $17.40,15.97 \mathrm{~kg} \cdot \mathrm{ha}^{-1} \mathrm{~mm}^{-1}$ and $14.88 \mathrm{~m}^{3} \cdot \mathrm{kg}^{-1} \mathrm{grain}$ for the BPW, ZT and CT treatments and water storage efficiency were $21.9,24.5$ and $29.2 \%$, for CT, ZT and BPW, respectively.
\end{abstract}

Key words: Conventional tillage, soil physical properties, water balance, water retention, zero tillage.

\section{INTRODUCTION}

Rice and wheat in sequence are cultivated in two contrasting soil environments. Rice requires soft, puddled and water-saturated soil conditions while wheat requires well aggregated and well aerated soil with fine tilth. Puddling (wet tillage) is the most common technique of land preparation for rice in South Asian countries. 
Puddling creates soil conditions ideal for rice cultivation but unsuitable for upland crops which follow rice (Sharma et al., 2003).

After rice harvest and puddled soils upon drying shrink become compact and hard, and develop surface cracks of varying sizes and shapes. The draught power requirement for tilling such soils is very high sometimes beyond the reach of local ploughs and small tractors. Nevertheless, when tilled, these soils often break into larger clods, having high breaking energy (Naresh et al., 2013).

In spite of spending significant time and energy, it is often difficult to obtain seedbeds with the desired tilth for sowing wheat. Wheat planted in seedbeds with coarse tilth due mainly to poor seed-soil contact, results in poor seedling emergence and unsatisfactory crop stands. This lowers wheat productivity. Frequent stirring opens the soil, breaks soil clods and aggregates. This enhances the oxidation of soil organic matter (Lal, 2008; He et al., 2009). The loose soils especially on sloping landscapes and in high rainfall areas are excessively prone to soil erosion. Thus, this system enhances land degradation and results in a decline in soil quality. To achieve satisfactory soil tilth, soils must be tilled at optimum moisture content. The optimum water content range in puddled soils is generally narrow (Naresh et al., 2013) and many times difficult for farmers to observe. Further, puddled soils may take from several weeks to months to dry and reach a moisture content optimum for tillage. This increases the lag time between rice harvest and wheat planting. The delayed sowing of wheat is another cause of low productivity in post-rice management. An estimate suggests each day delay in planting after November 15, lowers wheat yield by about $0.04 \mathrm{Mg} \cdot \mathrm{ha}^{-1}$ (Regmi et al., 2002).

Bread wheat (Triticum aestivum L.) is the most widely grown and consumed food crop and is the staple food for $35 \%$ of the world population (Rajaram et al., 2007). The irrigated wheat systems contribute over $40 \%$ of wheat production in the developing world (Rajaram et al., 2007).To meet the growing wheat demand, the global production need an 1.6 to $2.6 \%$ annual growth rate, which can be mainly achieved through improvement in input use efficiency (Rajaram et al., 2007). However, under the current production practices, crop productivity and input use efficiency has decreased /stagnated. In the Indo- Gangetic Plains (IGP), ground water is being depleted 13 to $17 \mathrm{~km}^{3}$.year ${ }^{-1}$ (Rodell et al., 2009) coupled with diminishing factor productivity (Ladha et al., 2003), an accelerated growth in crop productivity needs an enhanced resource use efficiency to meet the future wheat demand in the region. The improvement of input use efficiency in wheat cropping systems can be achieved through two main strategies: by adopting precise and more efficient crop management practices and germplasm (Reynolds et al., 2004). Tillage plays a key role in changing the hydro-physical properties. Blanco-Canqui and Lal (2007) indicated that water infiltration and runoff are closely related to the physical condition of the upper layer of the soil profile. Shaver et al. (2002) reported that physical properties such as bulk density and porosity near the soil surface are most important for dictating the infiltration characteristics of the soil at the soil-water interface. Francis et al. (1987) however, found that infiltration was more closely related to pore continuity than to porosity. Field experiments with zero tillage in wheat at several locations in the IndoGangetic plains have shown encouraging results (Jat et al., 2005; Saharawat et al., 2010).

Farmers have found direct drilling of wheat into postrice systems without tillage feasible and beneficial at several locations. Wheat yields with zero tillage are either equal or even better than those obtained with conventional tillage because of timely planting of wheat, efficient use of fertilizers and weed control. In addition, zero tillage is fuel and energy efficient but also reduces greenhouse gas emissions (Hill et al., 1991). Zero tillage systems conserve the land resource and are cost effective and efficient. Moreover, this tillage system also avoids challenges with clod formation.

Raised bed planting systems has been used since time immemorial by farmers in many parts of the world (Govaerts et al., 2007). Their application have traditionally been associated with water management issues, to reduce the adverse impact of excess water on crop production or to irrigate crops in semi-arid and arid regions (Sayre, 2004) where water productivity is comparatively low. A widely used application of raised beds in many semi-arid and arid areas is to plant crops on the edges of beds or ridges that are formed between furrows that carry irrigation water. With the lessons learnt from Mexico (semi-arid and sub-topical highlands), the raised bed planting system is being evaluated and advocated for many crops including wheat in south Asia (Saharawat et al., 2010).Conservation tillage has the potential to reduce soil erosion and input costs (Hobbs, 2007; Wuest et al., 2006).

There is some concern, however, that conservation tillage always improves soil properties for plant growth and water retention (Guy and Lauver, 2007). Research is needed therefore to understand the long-term impact of tillage and rice-wheat cropping systems on soil physical and hydraulic properties considered to be indicators of soil quality and water conservation. The objectives of the current study were to compare soil physical properties under zero and conventional tillage systems for a rice-

*Corresponding a uthor: E-mail: r.kna resh@ya hoo.com Author(s) agree that this article remain permanently open access under the terms of the Creative Commons Attribution Lic ense 4.0 Intemational License 
wheat cropping system and compare wheat yields, and wheat water use efficiency (WUE) for zero and conventional tillage systems.

\section{MATERIALS AND METHODS}

\section{Experimental site}

The experiment was conducted at the research farm $\left(29^{\circ} 4^{\prime} \mathrm{N}, 77^{\circ}\right.$ 46'E, $237 \mathrm{~m}$ above mean sea level) of the Sardar Vallabhbhai Patel University of Agriculture and Technology,Meerut,Uttar Pradesh,India, during 2009 to 2010 and 2011 to 2012. The climate of the area is semi-arid subtropical, characterized by very hot summers and cool winters. The hottest months are May and June, when the maximum temperature reaches 45 to $46^{\circ} \mathrm{C}$, whereas, during December and January, the coldest months of the year, the temperature often drops below $5^{\circ} \mathrm{C}$. The average annual rainfall is $765 \mathrm{~mm}, 75$ to $80 \%$ of which is received through the Northwest monsoon during July to September. The experimental soil (0 to 15 $\mathrm{cm}$ ) was sandy loam, with $165 \mathrm{~g}$ clay, $205 \mathrm{~g}$ silt and $620 \mathrm{~g}$ sand kg-1 that retained 18 and $7 \%$ water (mass basis) at 30 and $1500 \mathrm{kPa}$ water potential. Other soil characteristics include bulk density (0 to $15 \mathrm{~cm}$ ) of $1.59 \mathrm{Mg} \mathrm{m}^{-3}$; $\mathrm{pH}, 8.2$; organic $\mathrm{C}, 5.4 \mathrm{~g} \mathrm{~kg}^{-1}$; Olsen $\mathrm{P}, 10.5$ $\mathrm{mg} \mathrm{kg}^{-1}$ and $\mathrm{NH}_{4} \mathrm{OAc}$-extractable- $\mathrm{K}, 0.20 \mathrm{C} \mathrm{mol} \mathrm{kg}^{-1}$.

\section{Treatment details}

A field experiment was conducted in 2009 to 2010 and 2011 to 2012. Soil physical properties were measured for 2009 to 2010 year, and wheat yield and water use efficiency were also compared for three cropping seasons from 2009 to 2011 for different treatments. Three tillage systems (ZT:zero till-age; BPW:bed planted wheat and CT: conventional tillage) and four irrigation levels ( $\mathrm{I}_{1}$ :irrigation at crown root initiation (CRI); $\mathrm{I}_{2}$ :irrigation at $\mathrm{CRI+}$ jointing; $\mathrm{I}_{3}$ :irrigation at $\mathrm{CRI}+$ jointing+flowering; $\mathrm{I}_{4}$ :irrigation at $\mathrm{CRI}+$ jointing+flowering+dough) were tested. It is noted that each irrigation of about $5 \mathrm{~cm}$ measured by using a water meter (Dasmesh Co., India) was applied as surface flooding per treatment. One pre-sowing irrigation was applied to all plots. The total number of treatment combinations was twelve with three replications for 36 total numbers of plots and the size of per plot (10 $x 6.9 \mathrm{~m}) .\left(72 \mathrm{~m}^{2}\right.$ areas). The treatment effect was investigated for wheat crop (PBW-343) and the experimental design was a randomized complete block. Land preparation was done with the help of a power tiller.

\section{Soil physical properties}

Particle size analysis of surface and sub-surface soil samples (0 to $0.15 ; 0.15$ to $0.30 \mathrm{~m}$ ) was done using the pipette method (Gee and Or, 2002). Particle density of the soil was determined by the pycnometer method (Flint and Fint, 2002).The soil textural class was sandy loam and the particle density of the soil was 2.60 and $2.61 \mathrm{Mg} \cdot \mathrm{cm}^{-3}$, respectively for 0 to $0.15 ; 0.15$ to $0.30 \mathrm{~m}$ soil depths. The soil bulk density $\left(\rho_{b}\right)$ was determined before land preparation and 30-days after sowing of wheat by the core sampler method (Singh,1980), using metallic cores having $0.138 \mathrm{~m}$ length and 0.103 $\mathrm{m}$ internal diameter. Undisturbed soil cores were collected from the 0 to $0.60 \mathrm{~m}$ depth at $0.15 \mathrm{~m}$ depth intervals in all plots.Four soil cores were removed at each depth and the moist mass was recorded. Gravimetric moisture content was determined in a subsample of each soil core and was used to determine the dry mass of soil in each core.

The total porosity $(f)$ of the 0 to $0.15 \mathrm{~m}$ soil layer was determined at 30-days after seeding from data on particle density and $\rho_{b}$, using the following relationship:

$f=\left(1-\rho_{b} / \rho_{s}\right) \times 100$

Where, $f$ is the total porosity $(\%)$, $\rho b$ the bulk density $\left(\mathrm{Mg} \cdot \mathrm{m}^{-3}\right)$ and $\rho_{\mathrm{s}}$ the particle density $\left(\mathrm{Mg} \cdot \mathrm{m}^{-3}\right)$.

Undisturbed soil cores were collected from the 3 replicates in metal cores of $0.11 \mathrm{~m}$ length and $0.081 \mathrm{~m}$ diameter in the 0 to 0.15 $\mathrm{m}$ soil depth in zero-till, raised beds and conventionally-tilled plots at crop harvest.

\section{Infiltration measurements}

Infiltration of water into the soil was determined by the double ring in filtrometer (Bouwer, 1986), with a $21.5 \mathrm{~cm}$ inner diameter and 30 $\mathrm{cm}$ outer diameter cylinder inserted $14 \mathrm{~cm}$ into the soil (three replicates).Water entering the soil was measured with a calibrated Mariotte bottle. A constant water head of $15 \mathrm{~mm}$ was maintained in both rings.

The measurements were done at the initial soil water content corresponding to approximately field water capacity in all the treatments. This allowed to minimise the effect of different water content.The infiltration data were described according to Philip's (1969) model using the least squares method.

\section{Soil penetration resistance or (cone index)}

Soil penetrometer resistance (SPR) refers to the resistance offered by the soil to a metal probe pushed into soil. The SPR at field moisture content was determined in the 0 to 0.05 ; 0.05 to 0.15 and 0.15 to $0.30 \mathrm{~m}$ soil depths at tillering stage. A Proctor penetrometer having a $0.18 \mathrm{~m}$ long probe with a flat tip of $6 \mathrm{~mm}$ diameter was used for SPR determination. About five observations were made per plot at each depth for computing the average SPR.After recording the SPR value,soil samples from the layer of the same depth thickness were collected with the help of a tube auger for determining gravimetric moisture content.

\section{Soil aggregate analysis}

The air-dried soil sample $(100 \mathrm{~g})$ was placed on a $2 \mathrm{~mm}$ sieve and submerged in water for $5 \mathrm{~min}$ to allow slaking (Klute, 1986). The soils were then passed through a series of five sieves of $>2,2-1,1-$ $0.5,0.5$ to 0.25 and $<0.25 \mathrm{~mm}$ size (Gee and Or, 2002).

\section{Nutrient application}

Plant nutrients were applied as per the state recommendations for wheat $\left(\mathrm{N}_{120}+\mathrm{P}_{26}+\mathrm{K}_{50}\right) \cdot \mathrm{N}_{60}+\mathrm{P}_{26}+\mathrm{K}_{50}$ through urea,di-ammonium phosphate and muriate of potash respectively, were placed in band in seed rows at the time of sowing using zero till cum raised beds planter with enclined plate metering device. The remaining $N$ was broadcast with dry urea in two equal splits of $30 \mathrm{~kg} \cdot \mathrm{N} \cdot \mathrm{ha}^{-1},\left(\mathrm{~N}_{30}\right)$ at crown root initiation (CRI) and the flag leaf initiation (FLI) crop growth stages.

\section{Sowing techniques}

Wheat cultivar PBW-343 was sown on 20 November, 2009 using $100 \mathrm{~kg} \cdot \mathrm{seed} \cdot \mathrm{ha}^{-1} \mathrm{flat} / \mathrm{raised}$ bed planting was done using zero till cum raised beds planter with enclined plate metering device at a row spacing of $20 \mathrm{~cm}$. The bed: furrow width at top was kept at 107 
$\mathrm{cm}$ : $30 \mathrm{~cm}$ having six seed rows and the depth of the furrow was kept at $12 \mathrm{~cm}$. The plant population was maintained equal in flat as well as raised bed planting.

\section{Irrigation application and water productivity}

Wheat was irrigated at the crown root initiation, tillering, flowering and dough stages that corresponds to Z20, Z36, Z55 and Z83 (Zadoks et al., 1974).The total water use during the cropping was calculated as $\mathrm{m}^{3} \cdot \mathrm{ha}^{-1}$. The water productivity was calculated as grain yield produced per unit of irrigation water applied during cropping and was converted to $\mathrm{kg} \cdot \mathrm{grain} \cdot \mathrm{m}^{-3}$ water (Molden and Shaktivadivel, 1999; Kijne et al., 2003).

\section{Soil water content}

Soil water content was determined gravimetrically in the 0 to $0.60 \mathrm{~m}$ profile at $0.15 \mathrm{~m}$ depth intervals at sowing, one-day before and after each irrigation and at crop harvest. The mass wetness was converted into volume wetness for each soil layer using the $\rho_{b}$ of each respective soil layer.

\section{Soil water retention}

Undisturbed soil core samples, $0.05 \mathrm{~m}$ long and $0.60 \mathrm{~m}$ diameter were collected from each replication in the middle of the 0 to 0.075 $\mathrm{m}$ soil layer with metal cores at the flowering stage of wheat. Moisture content at -33 and $-1500 \mathrm{kPa}$ matric potential was determined with a pressure plate apparatus. Soil samples were saturated for $24 \mathrm{~h}$ on the porous plate and then equilibrated to the applied pressures. Plant-available water capacity (PAWC) was determined for each treatment at flowering stage of wheat as follows:

$P A W C=F C-P W P$

Where $\mathrm{FC}$ is the moisture retained at $-33 \mathrm{kPa}$ matric potential, and PWP (permanent wilting point) is the moisture retained at -1500 $\mathrm{kPa}$ matric potential.

\section{Soil water balance}

The water balance in the rootzone over a given period $\Delta t$ is given by

$\Delta S=P+I-E T-R-D+L i-L o$

Where $\Delta S$ is the change in soil-water storage in the root zone (that is between the soil surface and maximum rooting depth), $\mathrm{P}$ the precipitation, I the applied irrigation water, ET the evapotranspiration, $R$ the surface runoff the capillary rise (if negative) or drainage (if positive) at the maximum rooting depth, and $\mathrm{Li}$ and $\mathrm{Lo}$ are the lateral inflow and outflow, respectively.All components are expressed in units of length $(\mathrm{mm})$. The results shown by Cornelis et al. (2004) indicated that at the experimental site the drainage component at $105 \mathrm{~cm}$ was negligible. Therefore, the soil-water balance equation could be simplified as:

$\Delta S=P-E T-R$

Where soil-water storage $S$ was calculated between the soil surface and a depth of $120 \mathrm{~cm}$ using the trapeze rule, allowing to compute the evolution of evapotranspiration with time for the different treatments. Efficiency of soil management practice in terms of water
conservation

The soil management regime affects both the storage of precipitation water and its use by the crops. Since precipitation is the sole water supply in the irrigated area of the western Uttar Pradesh. We expressed the efficiency of the soil management practice in terms of precipitation storage efficiency (PSE) and precipitation use efficiency (PUE).PSE (Tanaka and Anderson, 1997) was calculated as the change in soil water storage within the 0 to $120 \mathrm{~cm}$ depth soil profile during the fallow period divided by precipitation during the fallow period. Runoff and erosion were also assumed to be negligible because the experiment is located on fairly level ground ( $<2 \%$ slope). The WUE was determined using the following equation:

$W U E=\frac{G Y}{G S E T}$

Where GY is grain yield $\left(\mathrm{kg} \mathrm{ha}^{-1}\right)$ and GSET $(\mathrm{mm})$ is growing season evapotranspiration.

\section{RESULTS AND DISCUSSION}

\section{Soil penetration resistance}

Soil penetration resistance (SPR) values, was determined immediately before the application of irrigation at the jointing stage of wheat in the 0.00 to 0.15 $\mathrm{m}$ soil layer are shown in Table 1. The SPR was significantly affected by tillage but the effect of irrigation treatments for the CT tillage system on SPR was nonsignificant.SPR values varied between 1.40 and 1.61 $\mathrm{MPa}$ with a mean value of $1.51 \mathrm{MPa}$ under $\mathrm{ZT}$; between 1.17 and $1.29 \mathrm{MPa}$ with a mean value of $1.24 \mathrm{MPa}$ under BPW and between 1.31 and $1.35 \mathrm{MPa}$ with a mean value of $1.33 \mathrm{MPa}$ under CT. The SPR was significantly higher under ZT than CT and BPW for all irrigation levels. The gravimetric soil moisture content was 16.6 to $18.3 \%$ under ZT, 14.3 to $17.9 \%$ under BPW and 17.3 to $18.8 \%$ under CT (Table 1). Soil penetration resistance (SPR) values averaged over four irrigation levels, determined at 0 to $0.05 \mathrm{~m} ; 0.05$ to $0.15 \mathrm{~m}$ and 0.15 to $0.30 \mathrm{~m}$ soil depths at crop harvest are shown in Table 2. The SPR at field moisture content (9.3 to $12.2 \%$ ) was higher in the ZT system than the CT system with a magnitude of about 4 times in the 0 to $0.05 \mathrm{~m}$ layer about 2 times in the 0.05 to $0.15 \mathrm{~m}$ layer and about 2.5 times in 0.15 to $0.30 \mathrm{~m}$ layer and lowest in BPW system with a magnitude of about 4.9 times in the 0 to $0.05 \mathrm{~m}$ layer about 2.9 times in the 0.05 to $0.15 \mathrm{~m}$ layer, and about 3.1 times in 0.15 to $0.30 \mathrm{~m}$ layer. Higher SPR in the ZT plots were found due to the higher soil $\rho b$ value $\left(1.77 \mathrm{Mg} \cdot \mathrm{m}^{-3}\right)$ in $\mathrm{ZT}$ plots compared to CT plots $\left(1.74 \mathrm{Mg} \cdot \mathrm{m}^{-3}\right)$ and BPW plots $\left(1.68 \mathrm{Mg} \mathrm{m}^{-3}\right)$ Table 2.

\section{Soil water retention}

Soil water retention characteristics were influenced by 
Table 1. Soil penetration resistance (SPR), and soil water content in the subsurface soil layer $(0.00$ to $0.15 \mathrm{~m})$ at tillering stage of wheat under different tillage and irrigation treatments measured during the 2009 to 2010 cropping season.

\begin{tabular}{lccc}
\hline Tillage treatment & Irrigation regime treatment & Gravimetric soil water content $\mathbf{( g / g} \%)$ & SPR (MPa) \\
\hline \multirow{2}{*}{ ZT } & $\mathrm{I}_{1}$ & $16.6^{\mathrm{de}}$ & $1.61^{\mathrm{a}}$ \\
& $\mathrm{I}_{2}$ & $16.9^{\mathrm{e}}$ & $1.55^{\mathrm{b}}$ \\
& $\mathrm{I}_{3}$ & $17.9^{\mathrm{bc}}$ & $1.44^{\mathrm{c}}$ \\
& $\mathrm{I}_{4}$ & $18.3^{\mathrm{c}}$ & $1.40^{\mathrm{d}}$ \\
& $\mathrm{I}_{1}$ & & $1.29^{\mathrm{a}}$ \\
$\mathrm{BPW}$ & $\mathrm{I}_{2}$ & $14.3^{\mathrm{c}}$ & $1.26^{\mathrm{ab}}$ \\
& $\mathrm{I}_{3}$ & $15.6^{\mathrm{e}}$ & $1.22^{\mathrm{c}}$ \\
& $\mathrm{I}_{4}$ & $16.8^{\mathrm{ab}}$ & $1.17^{\mathrm{d}}$ \\
& & $17.9^{\mathrm{c}}$ & \\
$\mathrm{CT}$ & $\mathrm{I}_{1}$ & & $1.35^{\mathrm{e}}$ \\
& $\mathrm{I}_{2}$ & $17.3^{\mathrm{bc}}$ & $1.33^{\mathrm{f}}$ \\
& $\mathrm{I}_{3}$ & $17.8^{\mathrm{a}}$ & $1.32^{\mathrm{ef}}$ \\
& $\mathrm{I}_{4}$ & $18.1^{\mathrm{dc}}$ & $1.31^{\mathrm{e}}$ \\
\hline
\end{tabular}

$\mathrm{ZT}=$ Zero tillage; $\mathrm{BPW}=\mathrm{Bed}$ planted wheat $\mathrm{CT}=$ Conventional tillage; $\mathrm{I}_{1}=$ Irrigation at $\mathrm{CRI}$ stage; $\mathrm{I}_{2}=$ Irrigation at $\mathrm{CRI}+\mathrm{jointing}$ stage; $I_{3}=$ Irrigationat $C R I+$ jointing+flowering stage; $I_{4}=$ Irrigation at $C R I+j o i n t i n g+f l o w e r i n g ~+d o u g h$ stage Note:The SPR values have been averaged over different irrigation treatments because of small differences in soil moisture content shows tandard error for comparism in the table.

Table 2. Soil penetration resistance (SPR);soil water content for three soil depths ,and total porosity (\%) in the zero tillage (ZT); bed planted wheat (BPW) and conventionally-tilled (CT) treatments measured at crop harvest during the 2009-10 cropping season.

\begin{tabular}{|c|c|c|c|c|c|c|c|}
\hline \multirow{2}{*}{ Tillage } & \multicolumn{2}{|c|}{$0-0.05 \mathrm{~m}$ soil depth } & \multicolumn{2}{|c|}{$0.05-0.15 \mathrm{~m}$ soil depth } & \multicolumn{2}{|c|}{$0.15-0.30 \mathrm{~m}$ soil depth } & \multirow[t]{2}{*}{ Total porosity (\%) } \\
\hline & Water content & SPR & Water content & SPR & Water content & SPR & \\
\hline & $(g / g \%)$ & $(\mathrm{MPa})$ & $(g / g \%)$ & (MPa) & $(g / g \%)$ & $(\mathrm{MPa})$ & \\
\hline$\overline{Z T}$ & $12.2^{\text {a† }}$ & $5.16^{\mathrm{a}}$ & $10.9^{\mathrm{a}}$ & 6.35 & $9.3^{a}$ & $8.36^{a}$ & $49.3^{a}$ \\
\hline BPW & $10.8^{\mathrm{a}}$ & $1.12^{\mathrm{b}}$ & $9.7^{b}$ & 2.16 & $7.2^{\mathrm{b}}$ & 2.69 & $66.8^{\mathrm{ab}}$ \\
\hline CT & $11.9^{b}$ & $1.28^{\mathrm{b}}$ & $11.6^{\mathrm{b}}$ & 3.12 & $11.4^{\mathrm{b}}$ & $3.39^{b}$ & $53.7^{b}$ \\
\hline
\end{tabular}

${ }^{\dagger}$ Means with different letters are significantly different at the 0.05 probability level.

tillage treatments as illustrated by the temporal variation in soil water content following the infiltration of surface water. Soil water content within about $36 \mathrm{~h}$ after infiltration of surface water in wheat was identical for all three tillage treatments. Water retention of the surface $0.075 \mathrm{~m}$ soil layer on a mass basis at -33 and $-1500 \mathrm{kPa}$ soil water pressure was always higher in CT than inZTplots.The differences however, narrowed with the decrease in water potential.

Water content on a volume basis was higher in the BPW than ZT system and lowest in the CT system at -33 and $-1500 \mathrm{kPa}$ pressure due to differences in $\rho_{b}$ (Table $3)$. The plant available water capacity (PAWC) on a volume basis was lower for the CT $(7.5 \%)$ than BPW $(7.6 \%)$ and highest in ZT (7.9\%) treatment (Table 3 ). Retention of less water against the force of gravity in BPW treatment does not collaborate previous findings that conservation tillage promotes water retention (Hill et al., 1985) due to improved soil structure and pore arrangement. Soil water retention ( 0 to $0.75 \mathrm{~m}$ soil layer) at-33 and $-1500 \mathrm{kPa}$ water pressures varied with tillage system. These differences could be explained with differences in pore size distribution since the water retention of soils depends primarily on the number and size distribution of soil pores and the specific surface area of soils. Pore size distribution affects water retention mainly at higher water potentials, such as those at saturation and field capacity, where the water retention is a function of soil structure. At lower water potentials, close to the permanent wilting point, the water retention is a function of soil texture, and also depends on the specific surface area of soil particles (Sharma and De Datta, 1994).

Tillage modified the soil structure thereby affecting water retention at $-33 \mathrm{kPa}$ water potential; however, tillage did not affect soil texture, hence differences in water retention betweenCT; ZT and BPW narrowed at- 
Table 3. Effect of tillage treatment on soil water retention at selected water potentials ( 0 to $0.075 \mathrm{~m}$ soil layer) for the $2009-10$ cropping season.

\begin{tabular}{lccc}
\hline \multirow{2}{*}{ Water potential (kPa) } & \multicolumn{3}{c}{ Volume wetness, $\left(\mathbf{m}^{3} / \mathbf{m}^{\mathbf{3}} \%\right)$} \\
\cline { 2 - 4 } & $\mathbf{Z T}$ & BPW & CT \\
\hline-33 & $36.5^{\mathrm{a}}$ & 41.8 & $33.5^{\mathrm{b}}$ \\
-1500 & $28.6^{\mathrm{a}}$ & 32.6 & $26.0^{\mathrm{b}}$ \\
PAWC & 7.9 & 7.6 & 7.5 \\
\hline
\end{tabular}

${ }^{\dagger}$ Means with different letters are significantly different at the 0.05 probability level. The comparisons were made between ZT; BPW and CT at respective pressures; Note: average bulk density values of soil cores were 1.34 and $1.23 \mathrm{Mg} \cdot \mathrm{m}^{-3}$ in ZT; BPW and CT plots, respectively; $\mathrm{ZT}=$ Zero tillage; $\mathrm{BPW}=$ Bed planted wheat $; \mathrm{CT}=$ Conventional tillage; PAWC: plant available water capacity.

Table 4. Effects of tillage and crop establishment methods on bulk density (3 years average, 2009-2010 to 20112012) in a 3 years wheat crop.

\begin{tabular}{lccccc}
\hline \multirow{2}{*}{ Tillage treatment } & \multirow{2}{*}{ Irrigation regime treatment } & $\mathbf{0 - 5} \mathbf{c m}$ & $\mathbf{6 - 1 0} \mathbf{c m}$ & $\mathbf{1 1 - 1 5} \mathbf{c m}$ & $\mathbf{1 6 - 2 0} \mathbf{~ c m}$ \\
\cline { 3 - 6 } & & \multicolumn{4}{c}{$\mathbf{M g ~ m}^{-\mathbf{3}}$} \\
$\mathrm{ZT}$ & $\mathrm{I}_{1}$ & $1.55^{\mathrm{cd} \S}$ & 1.60 & $1.74^{\mathrm{a}}$ & $1.76^{\mathrm{a}}$ \\
& $\mathrm{I}_{2}$ & $1.58^{\mathrm{b}}$ & 1.61 & $1.75^{\mathrm{a}}$ & $1.77^{\mathrm{a}}$ \\
& $\mathrm{I}_{3}$ & $1.50^{\mathrm{bc}}$ & 1.59 & $1.67^{\mathrm{b}}$ & $1.71^{\mathrm{b}}$ \\
& $\mathrm{I}_{4}$ & $1.47^{\mathrm{d}}$ & 1.57 & $1.66^{\mathrm{b}}$ & $1.70^{\mathrm{b}}$ \\
$\mathrm{BPW}$ & & & & \\
& $\mathrm{I}_{1}$ & $1.36^{\mathrm{a}}$ & 1.42 & $1.55^{\mathrm{a}}$ & $1.61^{\mathrm{a}}$ \\
& $\mathrm{I}_{2}$ & $1.39^{\mathrm{a}}$ & 1.46 & $1.57^{\mathrm{a}}$ & $1.63^{\mathrm{a}}$ \\
& $\mathrm{I}_{3}$ & $1.44^{\mathrm{b}}$ & 1.49 & $1.60^{\mathrm{b}}$ & $1.67^{\mathrm{b}}$ \\
$\mathrm{CT}$ & $\mathrm{I}_{4}$ & $1.47^{\mathrm{b}}$ & 1.53 & $1.64^{\mathrm{b}}$ & $1.68^{\mathrm{b}}$ \\
& & & & & \\
& $\mathrm{I}_{1}$ & $1.48^{\mathrm{a}}$ & 1.58 & $1.67^{\mathrm{b}}$ & $1.71^{\mathrm{b}}$ \\
& $\mathrm{I}_{2}$ & $1.50^{\mathrm{a}}$ & 1.59 & $1.67^{\mathrm{b}}$ & $1.71^{\mathrm{b}}$ \\
& $\mathrm{I}_{3}$ & $1.53^{\mathrm{c}}$ & 1.61 & $1.71^{\mathrm{b}}$ & $1.73^{\mathrm{a}}$ \\
& $\mathrm{I}_{4}$ & $1.57^{\mathrm{d}}$ & 1.64 & $1.72^{\mathrm{a}}$ & $1.74^{\mathrm{a}}$ \\
\hline
\end{tabular}

Within a column, means followed by the same letter are not different at the 0.05 level of probability.

$1500 \mathrm{kPa}$ water potential.The water retention on a volume basis at-33 and $-1500 \mathrm{kPa}$ pressure was higher under BPW than ZT and lowest under CT (Table 3). This occurred in part because of the higher $\rho_{b}$ under ZT than $C T$ and lowest in BPW. Although differences in PAWC between $\mathrm{ZT}$ and CT than BPW were not very large, the soil water retention under BPW was slightly better than under $\mathrm{ZT}$ and $\mathrm{CT}$ treatment.

\section{Soil bulk density $\left(\rho_{b}\right)$}

Bulk density $\left(\rho_{b}\right)$ is considered to be a measure of soil quality because of its impact on other soil properties such as porosity, soil water content, and hydraulic conductivity. Tillage and cropping systems can influence $\rho_{b}$, but any change in $\rho_{b}$ as a result of changing management practices is likely to be detected nearer the soil surface (Dam et al., 2005; Wuest et al., 2006). Numerous studies have investigated the effect of tillage practices on $\rho_{b}$. Fausey et al. (1994) found $\rho_{b}$ was $7 \%$ lower for no-tillage versus conventional tillage in continuous corn-oat-meadow rotations. Fausey et al. (1994) concluded after 28 years that $\rho_{b}$ was lowest in no-tillage due to the retention of more crop residue on the soil surface than in conventional tillage. Wuest et al. (2006) reported a temporal decline in soil strength or $\rho_{b}$ with adoption of no tillage. The $\rho_{b}$ was about $8.9 \%$ higher in ZT compared to CT plots (Table 4). In addition, no-tillage and reduced tillage systems generally result in higher bulk densities and smaller soil porosities (Dam et al., 2005).

Loch and Coughlan (1984) reported higher deep drainage under $\mathrm{ZT}$ than $\mathrm{CT}$ due to the presence of continuous macropores under ZT.Others have also found that no-tillage results in a higher $\rho_{b}$ near the soil surface than intensive tillage (Kay and Vanden Bygaart, 
Table 5. Soil aggregation status at wheat harvest as affected by tillage practices.

\begin{tabular}{|c|c|c|c|c|c|c|}
\hline \multirow{3}{*}{$\begin{array}{l}\text { Tillage } \\
\text { treatment }\end{array}$} & \multirow{3}{*}{$\begin{array}{l}\text { Irrigation } \\
\text { regime } \\
\text { treatment }\end{array}$} & \multicolumn{5}{|c|}{ Size distribution of aggregates, $\mathrm{mm}$} \\
\hline & & $>2$ & $2-1$ & $1-0.5$ & $0.5-0.25$ & $<0.25$ \\
\hline & & \multicolumn{5}{|c|}{ g aggregate $\mathrm{g}^{-1}$ dry soil } \\
\hline \multirow[t]{4}{*}{$Z \mathrm{ZT}$} & $I_{1}$ & $0.512^{\mathrm{a}}$ & $0.508^{\mathrm{ab}}$ & $0.421^{\mathrm{ab}}$ & $0.266^{\mathrm{ab}}$ & $0.120^{\mathrm{ab}}$ \\
\hline & $\mathrm{I}_{2}$ & $0.556^{\mathrm{ab}}$ & $0.514^{\mathrm{a}}$ & $0.498^{\mathrm{a}}$ & $0.311^{\mathrm{ab}}$ & $0.122^{\mathrm{a}}$ \\
\hline & $\mathrm{I}_{3}$ & $0.561^{\mathrm{a}}$ & $0.527^{\mathrm{a}}$ & $0.519^{\mathrm{a}}$ & $0.326^{\mathrm{ab}}$ & $0.132^{\mathrm{a}}$ \\
\hline & $\mathrm{I}_{4}$ & $0.614^{\mathrm{a}}$ & $0.590^{\mathrm{a}}$ & $0.566^{\mathrm{a}}$ & $0.358^{\mathrm{a}}$ & $0.152^{\mathrm{a}}$ \\
\hline \multirow[t]{4}{*}{ BPW } & $I_{1}$ & $0.363^{\mathrm{a}}$ & $0.128^{\mathrm{b}}$ & $0.116^{\mathrm{a}}$ & $0.110^{b}$ & $0.038^{\mathrm{C}}$ \\
\hline & $\mathrm{I}_{2}$ & $0.392^{\mathrm{a}}$ & $0.166^{\mathrm{b}}$ & $0.123^{\mathrm{a}}$ & $0.114^{\mathrm{b} \ddagger}$ & $0.059^{\mathrm{bc}}$ \\
\hline & $\mathrm{I}_{3}$ & $0.417^{\mathrm{a}}$ & $0.169^{b}$ & $0.166^{\mathrm{b}}$ & $0.138^{\mathrm{b}}$ & $0.066^{\mathrm{a}}$ \\
\hline & $\mathrm{I}_{4}$ & $0.427^{\mathrm{a}}$ & $0.213 d$ & $0.157^{b}$ & $0.150^{\mathrm{b} \ddagger}$ & $0.088^{\mathrm{a}}$ \\
\hline \multirow[t]{4}{*}{ CT } & $\mathrm{I}_{1}$ & $0.222^{\mathrm{b}}$ & $0.196^{b}$ & $0.183^{b}$ & $0.173^{\mathrm{a}}$ & $0.091^{\mathrm{a}}$ \\
\hline & $\mathrm{I}_{2}$ & $0.332^{\mathrm{c}} \mathrm{d}$ & $0.218^{\mathrm{b}}$ & $0.191^{b}$ & $0.192^{\mathrm{a}}$ & $0.100^{\mathrm{abc}}$ \\
\hline & $\mathrm{I}_{3}$ & $0.442^{\mathrm{bc}}$ & $0.297^{\mathrm{a}}$ & $0.230^{a b}$ & $0.208^{\mathrm{a}}$ & $0.104^{a}$ \\
\hline & $\mathrm{I}_{4}$ & $0.444^{\mathrm{a}}$ & $0.360^{\mathrm{a}}$ & $0.244^{\mathrm{b}}$ & $0.214^{\mathrm{a}}$ & $0.144^{\mathrm{a}}$ \\
\hline
\end{tabular}

${ }^{\ddagger}$ Values followed by a similar letter within an aggregate size fraction are not significantly different at $P<0.05$ level of significance.

2002). Tillage largely influences pore size distribution. Soils under conventional tillage (CT) generally have lower bulk density and associated higher total porosity within the plough layer than under no tillage (ZT). The changes in total porosity are related with alterations in pore size distribution. This relation can be different depending on soil type.

Schjønning and Rasmussen (2000) reported that under the same site conditions, ZT compared to CT resulted in lower volume of macro-pores $(>30 \mu \mathrm{m})$ on sandy soil and silty loam, whereas the opposite effect was found on sandy loam. The bulk density did varied significantly due to planting techniques and it was significantly reduced under raised bed planting compared to flat sowing. This was attributed mainly due to more pore spaces created in the beds through modified land configuration by accumulations of the topsoil. Bed planting provides natural opportunity to reduce compaction by confining traffic to the furrow bottoms (Govaerts et al., 2006).

Liebig et al. (2004) and Wuest et al. (2006) concluded that soil properties as affected by tillage and cropping systems were largely limited to the surface $0.075 \mathrm{~m}$ (2.95 in) of the soil profile.

\section{Size distribution of aggregates}

Aggregate size distributions were significantly $(P>0: 05)$ influenced by tillage treatments (Table 5). The results are presented as these four groups. Generally, the quantity of fine aggregates $(<0.25 \mathrm{~mm})$ was much higher than coarse aggregates $(>0.25 \mathrm{~mm})$. About $5 \%$ of the aggregates were larger than $2 \mathrm{~mm}, 7 \%$ between 1 and 2 $\mathrm{mm}, 13 \%$ between 1 and $0.5 \mathrm{~mm}$, about $20 \%$ were in the range of $0.5-0.25 \mathrm{~mm}$, and almost $65 \%$ of the aggregates had the size smaller than $0.25 \mathrm{~mm}$. Aggregate size distributions were significantly $(P>0: 05)$ influenced by tillage treatments. Aggregates $<25 \mathrm{~mm}$ in the zero tillage category was significantly higher $(4.4 \%)$, than conventional tillage (CT) and beds planted wheat (BPW) methods (3.2 and $3.4 \%$, respectively).

The zero till methods also had the highest amount of 1 to $2 \mathrm{~mm}$ aggregates $(5.9 \%)$ while the beds planted method contained the lowest amount of this size of aggregates $(4.5 \%)$. The percentage of the aggregates with other sizes ( 1 to $0.5,0.5$ to 0.25 and $<0.25 \mathrm{~mm}$ ) were similarly influenced $(P>0: 05)$ by different tillage practices.

Some studies generally indicate that no-tillage and reduced tillage systems have positive impacts on conserving soil and water resources by reducing soil erosion, retaining more water in the soil profile, increasing water infiltration and enhancing soil aggregation and stability (Dam et al. 2005).Aggregates in the range $>2,2$ to 1,1 to 0.5 , and 0.5 to $0.25 \mathrm{~mm}$ were all significantly $(P>0: 05)$ higher in the zero till method compared to other treatments. Generally, soil organic carbon is a basic factor affecting aggregation (Elliott, 1986). Bear et al. (1994) reported that aggregates ranging from 2 to $0.25 \mathrm{~mm}$ in size need to be protected by organic carbon binding agents otherwise, under heavy and intensive cultivation, the aggregates would be disrupted.

Angers and Mehuys (1989) also reported that in a clay soil of a humid region applying a no-till system resulted in in conserving a higher amount of organic carbon and 
Table 6. Effects of tillage and crop establishment methods on steady-state infiltration rate in a 3 years wheat crop.

\begin{tabular}{|c|c|c|c|c|}
\hline \multirow{2}{*}{ Tillage treatment } & \multirow{2}{*}{ Irrigation regime treatment } & $2009-2010$ & 2010-2011 & 2011-2012 \\
\hline & & \multicolumn{3}{|c|}{$\mathrm{cm} \mathrm{h}^{-1}$} \\
\hline \multirow{4}{*}{ ZT } & $I_{1}$ & $0.20^{\mathrm{ab}}$ & $0.23^{\mathrm{C}}$ & $0.27^{\mathrm{b}}$ \\
\hline & $\mathrm{I}_{2}$ & $0.18^{\mathrm{c}}$ & $0.20^{\mathrm{c}}$ & $0.23^{\mathrm{a}}$ \\
\hline & $\mathrm{I}_{3}$ & $0.14^{\mathrm{C}}$ & $0.16^{\mathrm{d}}$ & $0.14^{\mathrm{c}}$ \\
\hline & $\mathrm{I}_{4}$ & $0.12^{\mathrm{C}}$ & $0.13^{d}$ & $0.13^{\mathrm{c}}$ \\
\hline \multirow{4}{*}{ BPW } & $l_{1}$ & $0.46^{\mathrm{a}}$ & $0.48^{\mathrm{a}}$ & $0.44^{\mathrm{a}}$ \\
\hline & $\mathrm{I}_{2}$ & $0.35^{\mathrm{b}}$ & $0.35^{\mathrm{b}}$ & $0.43^{\mathrm{a}}$ \\
\hline & $\mathrm{I}_{3}$ & $0.32^{\mathrm{b}}$ & $0.32^{\mathrm{b}}$ & $0.39^{\mathrm{ab}}$ \\
\hline & $\mathrm{I}_{4}$ & $0.31^{\mathrm{b}}$ & $0.33^{\mathrm{b}}$ & $0.34^{\mathrm{bc}}$ \\
\hline \multirow{4}{*}{ CT } & $I_{1}$ & $0.34^{\mathrm{b}}$ & $0.31^{b}$ & $0.27^{\mathrm{ab}}$ \\
\hline & $\mathrm{I}_{2}$ & $0.32^{\mathrm{c}}$ & $0.30^{\mathrm{b}}$ & $0.26^{\mathrm{abc}}$ \\
\hline & $\mathrm{I}_{3}$ & $0.32^{\mathrm{b}}$ & $0.29^{b}$ & $0.24^{\text {abct }}$ \\
\hline & $\mathrm{I}_{4}$ & $0.28^{\mathrm{b}}$ & $0.25^{\mathrm{a}}$ & $0.21^{\mathrm{bc}}$ \\
\hline
\end{tabular}

"Within a column, means followed by the same letter are not different at the 0.05 level of probability

more stable aggregates compared to other tillage treatments.

\section{Infiltration}

The steady state infiltration rate at wheat harvest had differences in treatments and with time (Table 6). It was consistently highest with an overall average of $0.37 \mathrm{~cm}$ $\mathrm{h}^{-1}$ in (raised bed), lowest at $0.18 \mathrm{~cm} \mathrm{~h}^{-1}$ in zero till and intermediate $\left(0.27\right.$ to $\left.0.30 \mathrm{~cm} \mathrm{~h}^{-1}\right)$ in conventional till treatment. The time trend showed a decline $(0.02$ to $0.03 \mathrm{~cm}$ $\mathrm{h}^{-1}$ year $^{-1}$ ) in infiltration rate in $\mathrm{T}_{1}$ and $\mathrm{T}_{2}$, and an increase (0.01 to $0.03 \mathrm{~cm} \mathrm{~h}^{-1}$ year ${ }^{-1}$ ) in $\mathrm{T}_{3}$ and $\mathrm{T}_{4}$ (Table 6).

Infiltration decreased with time in conventional tillage, probably because of progressive destruction in soil structure and an increase in subsoil compaction. Infiltration after ZT and raised beds increased with time, indicating improvement in soil structure, as also supported by soil aggregation. Savabi et al. (2007) reported that $\mathrm{ZT}$ in medium textured soils (silty loam and silty clay loam) enhanced infiltration rates with time.

Arshad et al. (2004) found average infiltration was 30\% lower under conventional tillage as compared with notillage in western Canada. No-tillage practices have been reported to maintain and sometimes enhance soil aggregation (Liebig et al., 2004), increase soil porosity (Dam et al. 2005), and produce more root channels (Kennedy and Schillinger 2006).Tillage-based cropping systems, like the BPW treatment in this study, may cause more surface sealing or a shear plane at the depth of tillage (tillage pan) and therefore impede water infiltration. Tillage also mechanically breaks pore continuity and hinders biopore formation which reduces infiltration in CT.Infiltration rate is the functions of pore size distribution. Both of these processes increase with an increase in soil macro porosity.

Raised beds caused loosening of the surface soil layer thereby increasing the macroporosity and hence increasing the infiltration rate. Higher values of infiltration under CT than ZT were also reported by (Barzegar et al., 2004). The situation however, may be different under continuous zero till systems than in rice-wheat system. A soil continuously under zero till management especially when crop residues are left on the soil surface may show higher infiltration rates values due to root channels formed in soil and enhanced earthworm activity as was observed by (Barnes and Ellis, 1979).Several other workers reported higher infiltration rate under ZT system due to the formation of continuous soil bio-pores (Ehlers, 1975; Unger and Cassel, 1991).

The changes in pore characteristics induced by tillage, had a substantial effect on cumulative infiltration.BPW with 14 treatment of irrigation scheduling had the highest infiltration throughout the time of water application. The differences in initial infiltration and reduction of infiltration rate with time among tillage treatments imply higher capability of BPW pore system to increase amount of water infiltrating before filling macro-pores and reaching steady state.

This can be supported by higher contribution of large pores (Table 5) and flow-active porosity throughout the profile in BPW than in the remaining treatments. Our infiltration data contrast with results showing that pores in ZT can be more effective in transmitting water than in CT (Kay, 1990; McGarry et al., 2000). 
Table 7.Yield and PUE for the different tillage practices in a 3 year wheat crop under study.

\begin{tabular}{lcccc}
\hline Tillage treatment & Tillage practice & PSE (\%) & Yield $\left(\mathbf{k g ~ h a}^{-1}\right)$ & PUE $\left(\mathbf{k g ~ m}^{-3}\right)$ \\
\hline ZT & $\mathrm{I}_{1}$ & 21.9 & $3485^{\mathrm{bc}}(62)$ & 0.38 \\
& $\mathrm{I}_{2}$ & 23.8 & $3800^{\mathrm{ab}}(100)$ & 0.54 \\
& $\mathrm{I}_{3}$ & 27.3 & $3928^{\mathrm{c}}(142)$ & 0.66 \\
& $\mathrm{I}_{4}$ & 24.9 & $4270^{\mathrm{ab}}(190)$ & 0.57 \\
BPW & & & \\
& $\mathrm{I}_{1}$ & 23.0 & $3609^{\mathrm{ab}}(116)$ & 0.53 \\
& $\mathrm{I}_{2}$ & 20.8 & $3975^{\mathrm{b}}(235)$ & 0.62 \\
& $\mathrm{I}_{3}$ & 39.2 & $4249^{\mathrm{c}}(366)$ & 0.75 \\
CT & $\mathrm{I}_{4}$ & 33.7 & $4569^{\mathrm{bc}}(472)$ & 0.71 \\
& & & \\
& $\mathrm{I}_{1}$ & 20.5 & $3789^{\mathrm{ab}}(85)$ & 0.83 \\
& $\mathrm{I}_{2}$ & 19.9 & $4323^{\mathrm{bc}}(97)$ & 0.84 \\
& $\mathrm{I}_{3}$ & 24.4 & $4468^{\mathrm{cd}}(168)$ & 0.64 \\
\hline
\end{tabular}

Values between brackets indicate standard error. Average values in the same column followed by the same letter are not significantly different according to Student-Newman-Keuls test (á = 0.05).

Greater infiltration of soil under BPW (CA) than ZT and CT in our study can be due to relatively low susceptibility to sealing that could stop the entry of water to the high interaggregate flow-active porosity in BPW.It is worthy to note that the pore structure under BPW allowing the improved infiltration, persisted until the end of growing season when the measurements were conducted. It indicates that soil in BPW did not show a characteristic trend for BPW soil to become less porous with time (Horn, 2004).Delayed densification of the BPW soil in our study could be associated with stable aggregate structure and optimum moisture conditions during tillage. Favourable effect of tillage at the optimum moisture on the stability of soil structure has been reported earlier by Vez (1979) for a similar soil type. Shaver et al. (2002) reported that physical properties such as bulk density and porosity near the soil surface are most important for dictating the infiltration characteristics of the soil at the soil-water interface.

\section{Effect of tillage on water conservation and precipitation use efficiency}

The effectiveness of the tillage practices in storing rainwater relative to the amount of rainfall during the fallow period, expressed in terms of PSE, in yield and use of effective rainfall, expressed as PUE is summarised in Table 7.Tillage practices significantly influenced PSE.It was greatest for BPW and ZT, followed by CT.The water storage efficiency were $21.9,24.5$ and $29.2 \%$,for CT,ZT and BPW, respectively.

Soil water profile data indicated that on average $\mathrm{ZT}$ stored the most water in the 0 to $30 \mathrm{~cm}$ zone and this was significantly so when compared to CT.Below this zone, $\mathrm{ZT}$ stored the least amount of water and this was significantly so in the 30 to $120 \mathrm{~cm}$ zone. The BPW stored less water than CT and ZT in the 0 to $30 \mathrm{~cm}$ zone but stored the highest in the 30 to $120 \mathrm{~cm}$ zone.

It was shown that the effect of conservation tillage compared to conventional tillage was most pronounced during the driest and normal years. During those years, BPW was the best practice in terms of conservation of water and crop yield. It showed the highest increase in water storage during the fallow period, and the highest yields, and precipitation use efficiencies (PUE). ZT also showed relatively good results, followed by CT.

\section{Water use efficiency}

Tillage treatments showed a significant effect on water use efficiency (WUE) during the 2009 to 2010 cropping year (Table 8). Numerically, the highest WUE of 15.47 $\mathrm{kg} \cdot \mathrm{ha}^{-1} \cdot \mathrm{mm}^{-1}$ was found under BPW treatment and the lowest of $13.38 \mathrm{~kg} \cdot \mathrm{ha}^{-1} \cdot \mathrm{mm}^{-1}$ under CT.Conversely, the amount of water used $\left(\mathrm{m}^{3}\right)$ to produce $1 \mathrm{~kg}$ of wheat grain varied between $2.03 \mathrm{~m}^{3} \cdot \mathrm{kg}^{-1}$ in ZT and $2.51 \mathrm{~m}^{3} \cdot \mathrm{kg}^{-1}$ in CT treatments. Similar to grain yield data, the WUE for 2010 to 2011 and 2011 to 2012 cropping seasons were different. During 2010 to 2011, the highest WUE (18.25 $\mathrm{kg} \cdot \mathrm{ha}^{-1} \cdot \mathrm{mm}^{-1}$ ) was obtained with BPW and the lowest $\left(16.87 \mathrm{~kg} \cdot \mathrm{ha}^{-1} \cdot \mathrm{mm}^{-1}\right)$ with the CT and ZT treatment(Table 8).

\section{Conclusions}

Water is the most limiting factor for crop production in 
Table 8. Tillage effects on change in soil water storage, soil water depletion and water use efficiency under wheat crop during 2009 to 2010 to 2011 to 2012 .

\begin{tabular}{lccc}
\hline Tillage & $\mathbf{2 0 0 9 - 2 0 1 0}$ & $\mathbf{2 0 1 0 - 2 0 1 1}$ & 2011-2012 \\
\hline mm $305 \mathrm{~mm}^{-1}$ soil depth & & & \\
Water storage & & & \\
ZT & $137.73^{\mathrm{a}}$ & $171.56^{\mathrm{ab}}$ & $160.02^{\mathrm{a}}$ \\
BPW & $161.29^{\mathrm{a}}$ & $186.82^{\mathrm{a}}$ & $191.71^{\mathrm{a}}$ \\
CT & $150.43^{\mathrm{a}}$ & $183.13^{\mathrm{a}}$ & $188.92^{\mathrm{a}}$ \\
& & & \\
Water depletion & & & \\
ZT & $174.63^{\mathrm{a}}$ & $192.47^{\mathrm{a}}$ & $210.88^{\mathrm{a}}$ \\
BPW & $189.48^{\mathrm{a}}$ & $215.90^{\mathrm{a}}$ & $216.41^{\mathrm{a}}$ \\
CT & $197.87^{\mathrm{a}}$ & $225.17^{\mathrm{a}}$ & $228.03^{\mathrm{a}}$ \\
kg ha ${ }^{-1} \mathrm{~mm}^{-1}$ soil depth & & & \\
Water use efficiency & & & \\
ZT & & & \\
BPW & $14.13^{\mathrm{a}}$ & $17.86^{\mathrm{a}}$ & $15.91^{\mathrm{a}}$ \\
CT & $15.47^{\mathrm{a}}$ & $18.25^{\mathrm{ab}}$ & $18.48^{\mathrm{a}}$ \\
\hline
\end{tabular}

irrigated farming in the western Uttar Pradesh. This study showed that from a water conserving perspective, conservation tillage (ZT and BPW) could be an ecologically sound approach in the irrigated areas in the western Uttar Pradesh.BPW practices significantly increased the precipitation storage efficiency and the water use efficiency. Over our study period (2009 to 2012) BPW was the most suitable conservation tillage. Although in general, ZT had a positive effect on yield which may be an indication that in the longer term, it may be as good an alternative as BPW.

The irrigation treatments did not affect soil physical properties but tillage systems did affect these properties. The $\rho_{b}$ and SPR values of BPW plots were 8.2 and $13 \%$, respectively, lower compared to ZT plots which increased the porosity $(8.9 \%)$ and the steady infiltration rate $(4.5$ times) under BPW plots. The rice crop management, rice crop was grown previous to the wheat crop, created adverse soil conditions which partially caused the lower values of infiltration rate in wheat plots which followed rice. When comparing tillage systems, the soil was loosened with a plough for BPW which decreased the $\rho_{b}$, increased soil porosity as well as the steady infiltration rate compared to zero-tilled wheat at the time of crop harvest.

The improved soil properties under BPW systems improved the wheat yield; however the yield differences were significant between tillage treatments during the all three cropping year. Zero-till wheat provided better soil physical conditions, namely soil $\rho_{b}$, SPR, infiltration, and soil distribution of aggregates for $\mathrm{R}-\mathrm{W}$ system productivity through physical manipulation of soil as well as changes in SOC content.

\section{Conflicts of Interest}

The authors have not declared any conflict of interest.

\section{ACKNOWLEDGEMENTS}

The authors are grateful to the Director Research of the Sardar Vallabhbhai Patel University of Agriculture and Technology Meerut U.P., India for providing facilities and encouragement. The financial support received from the Uttar Pradesh council of Agricultural Research, Lucknow during the course of the study is gratefully acknowledged.

\section{REFERENCES}

Angers DA, Mehuys GR (1989). Effects of cropping on carbohydrate content and water-stable aggregation of a clay soil. Can. J. Soil Sci. 69:373-380. http://dx.doi.org/10.4141/cjss89-037

Arshad MA, Franzluebbers AJ, Azooz RH (2004). Surface-soil structural propertiesunder grass and cereal production on a Mollic Cyroboralf in Canada. Soil Tillage Res. 77(1):15-23. http://dx.doi.org/10.1016/j.still.2003.10.004

Barzegar R, Asoodar MA, Eftekhar AR, Herbert SJ (2004). Tillage effects on soil physical properties and performance of irrigated wheat and clover in semi arid region. J. Agron. 3 (4):237-242. http://dx.doi.org/10.3923/ja.2004.237.242

Barnes BT, Ellis FB (1979). Effects of different meth-ods of cultivation and direct drilling, and disposal of straw residues on populations of earthworms. J. Soil Sci. 30:669-679. http://dx.doi.org/10.1111/j.13652389.1979.tb01016.x

Bear MH, Hendrix PF, Coleman DC (1994). Water stable aggregates and organic carbon fractions in conventional and no-tillage soils. Soil Sci. Soc. Am. J. 58:777-786 http://dx.doi.org/10.2136/sssaj1994.03615995005800030020x

Blanco-Canqui H, Lal R (2007).Impacts of long-term wheat straw management on soil hydraulic properties under no-tillage. Soil Sci. Soc. Am. J. 71:1166-1173. http://dx.doi.org/10.2136/sssaj2006.0411 
Bouwer H (1986). Intake rate:cylinder infiltrometer. In:Klute, A.(Ed.),Methods of Soil Analysis, Part 1. Physical and Mineralogical Properties, Monograph 9. ASA, Madison, WI, pp. 825-843.

Cornelis WM, Wu HJ, Schiettecatte W, Jin K, Hartmann R, Gabriels D,

Cai DX (2004). Conservation tillage practices on a dryland winter wheat field in northern China: a soil-water balance study using a trime tube probe. Acta Agrophys. 4:25-36.

Dam RF, Mehdi BB, Burgess MSE, Madramootoo CA, Mehuys GR, Callum IR (2005). Soil bulk density and crop yield under eleven consecutive years of corn with different tillage and residue practices in a sandy loam soil in central Canada. Soil Tillage Res. 84(1):41-53. http://dx.doi.org/10.1016/j.still.2004.08.006

Ehlers W (1975). Observations on Earthworm Channels and Infiltration on Tilled and Untilled Loess Soil. Soil Sci. 119:242-249. http://dx.doi.org/10.1097/00010694-197503000-00010

Elliott ET (1986). Aggregate structure and carbon, nitrogen and phosphorous in native and cultivated soils. Soil Sci. Soc. Am. J. 50:627-633 http://dx.doi.org/10.2136/sssaj1986.03615995005000030017x

Fausey NR, Lal R, Mahboubi AA (1994). Long-term tillage and rotations effects on properties of a central Ohio soil. Soil Sci. Soc. Am. J. 58(2):517-522. http://dx.doi.org/10.2136/sssaj1994.03615995005800020038x

Flint A, Flint LE (2002). Particle Density," In: J. H. Dane and G. C. Topp, Eds., Laboratory Methods of Soil Analysis, Part 4: Physical Methods, SSSA, Madison, pp. 229-240.

Francis GS, Cameron KC, Swift RS (1987). Soil physical conditions after six years of direct drilling or conventional cultivation on a silt loam soil in New Zealand. Australian J. Soil Res. 25(4):517-529. http://dx.doi.org/10.1071/SR9870517

Gee GW, Or D (2002). Particle-Size Analysis," In: J.H. Dane and G. C. Topp, Eds., Methods of Soil Analysis, Part 4, Physical Methods, SSSA Book Series 5,SSSA, Madison, pp. 255-294.

Govaerts B, Sayre KD, Ceballos-Ramirez JM, Luna-Guido ML, LimonOrtega A, Deckers J, Den-dooven L (2006). Conventionally Tilled and Permanent Raised Beds with Different Crop Residue Management:Effect on Soil C and N Dynamics. Plant Soil 280:143155. http://dx.doi.org/10.1007/s11104-005-2854-7

Govaerts B, Sayre KD, Lichter K, Dendooven L, Deckers J (2007). Influence of Permanent Raised Bed Planting and Residue Management on Physical and Chemical Soil Quality in Rainfed Maize/Wheat Systems. Plant Soil 291(1-2):39-54. http://dx.doi.org/10.1007/s11104-006-9172-6

Guy SO, Lauver MA (2007). No-till and conventional-till effects on spring wheat in the Palouse. Crop Management (May 2007):1-3.

He J, Kuhn NJ, Zhang XM, Zhang XR, Li HW (2009). Effects of 10 Years of Conservation Tillage on Soil Properties and Productivity in the Farming-Pastoral Ecotone of Inner Mongolia, China. Soil Use Manage. 25(2):201-209. http://dx.doi.org/10.1111/j.14752743.2009.00210.x

Hill RL, Horton R, Cruse RM (1985). Tillage effects on soil water retention and pore size distribution of two Mollisols. Soil Sci. Soc. Am. J. 49(5):1264-1270.

Hill JE, Bayer DE, Bocchi S, Clampett WS (1991). Direct Seeded Rice in the Temperate Climates of Australia," Direct Seeded Flooded Rice in the Tropics, IRRI, Manila, pp. 91-102.

Hobbs PR (2007). Conservation agriculture: What is it and why is it important for future sustainable food production? J. Agric. Sci. 145(1):127-137. http://dx.doi.org/10.1017/S0021859607006892

Horn R (2004). Time dependence of soil mechanical properties and pore functions for arable soils. Soil Sci. Soc. Am. J. 68:1131-1137. http://dx.doi.org/10.2136/sssaj2004.1131

Jat ML, Singh S, Rai HK, Chhonkar RS, Sharma SK, Gupta RK (2005). Furrow Irrigated Raised Bed Planting Technique for Diversification of Rice-Wheat System of Indo-Gangetic Plains. J. Japan Association for Int. Cooperation Agric. Forest. 28:25-42.

Kay BD (1990). Rates of change of soil structure under different cropping systems. Adv. Soil Sci. 12:1-52. http://dx.doi.org/10.1007/978-1-4612-3316-9_1

Kay BD, VandenBygaart AJ (2002). Conservation tillage and depth stratification of porosity and soil organic matter. Soil Tillage Res. 66(2):107-118. http://dx.doi.org/10.1016/S0167-1987(02)00019-3
Kennedy AC, Schillinger WF (2006). Soil quality and water intake in traditional-till vs. no-till paired farms in Washington's Palouse region. Soil Sci. Soc. Am. J. http://dx.doi.org/10.2136/sssaj2005.0160

Klute A (Ed.) (1986). Methods of Soil Analysis.Part 1.Physical and Mineralogical Methods, Soil Sci. Soc. Am. Agronomy Monograph No. 9, $2^{\text {nd }}$ Edition

Kijne JW, Barker R, Molden D (2003). Water productivity in agriculture: Limits and Opportunities for Improvement. Wallingford, P. 332.

Lal R (2008). Soils and sustainable agriculture: A review. Agron. Sustain. Develop http://dx.doi.org/10.1080/10440040802121395

Liebig MA, Tanaka DL, Wienhold BJ (2004). Tillage and cropping effects on soil quality indicators in the northern Great Plains. Soil Tillage Res. http://dx.doi.org/10.1016/j.still.2004.02.002

Loch RJ, Coughlan KJ (1984). Effects of zero till and stubble retention or some properties of cracking clay. Australian J. Soil Res. 22:91-98. http://dx.doi.org/10.1071/SR9840091

Ladha JK, Pathak H, Padre AT, Dawe D, Gupta RK (2003). Productivity trends in intensive rice-wheat cropping systems in Asia", In:J. K.Ladha, et al., Eds., Improving the Productivity and Sustainability of Rice-Wheat Systems: Issues and Impacts, ASA Spec. Publ. 65, ASA, CSSA and SSSA, Madison, pp. 45-76. http: //dx. doi.org/10.2134/asaspecpub65.c3

McGarry D, Bridge BJ, Radford BJ (2000). Contrasting soil physical properties after zero and traditional tillage of an alluvial soil in the semi-arid subtropics. Soil Till. Res. 53:105-115. http://dx.doi.org/10.1016/S0167-1987(99)00091-4

Molden D, Shaktivadivel R (1999). Water accounting to assess use and productivity of water. Water Res. Dev. 15(1-2):55-71. http://dx.doi.org/10.1080/07900629948934

Naresh RK, Singh SP, Kumar V (2013). Crop establishment,tillage and water management technologies on crop and water Productivity in the rice-wheat cropping system of North West-India. Int. J. Life Sci. Bt. Pharm. Res. 2(3):237-248.

Naresh RK,Tomar SS,Samsher,Purushottam,Singh SP,Kumar D, Dwivedi A, Kumar V (2014). Experiences with Rice grown on Permanent Raised Beds:Effect of Water Regime and Planting Techniques on Rice yield,Water use,Soil Properties and Water productivity.Rice $\quad$ Science $21 \quad$ (3):170-180. http://dx.doi.org/10.1016/S1672-6308(13)60185-7

Philip JR (1969). The theory of infiltration. Adv. Hydrosci. 5:215-296. http://dx.doi.org/10.1016/B978-1-4831-9936-8.50010-6

Rajaram S, Sayre KD, Diekmann J, Gupta R, Erskine W (2007). Sustainability Considerations in Wheat Improvement and Production. In: M.S.Kang,Ed., Agricultural and Environmental SustainabilityConsiderations for Future, Haworth Food \& Agricultural Products Press, New York, pp. 105-124.

Regmi P, Ladha J, Pathak K, Pasuquin H, Bueno C, Dawe D, Hobbs PR, Joshy D, Maskey SL, Pandey SP (2002). Yield and Soil Fertility Trends in a 20-Year Rice-Rice-Wheat Experiment in Nepal. Soil Sci. Soc. Am. J. 66:857-867. http://dx.doi.org/10.2136/sssaj2002.0857

Reynolds MP, Trethowan R, Crossa J, Vargas M, Sayre KD (2004). Physiological factors associated with genotype by environment interaction in wheat. Field Crops Res. 85:253-274. http://dx.doi.org/10.1016/S0378-4290(03)00057-1

Rodell M, Velicogna I, Famiglietti JS (2009). Satellite-based estimates of groundwater depletion in India. Nature 460:999-1002. http://dx.doi.org/10.1038/nature08238

Sharma PK, De Datta SK (1994). Rainwater Utilization Efficiency in Rainfed Lowland Rice. Adv. Agron. 52:101. http://dx.doi.org/10.1016/S0065-2113(08)60622-7

Sharma PPK, Ladha JK, Bhushan LL (2003). Soil physical effects of puddling in rice-wheat cropping systems. Improving the Productivity and Sustainability of Rice- Wheat Systems: Issues and Impacts. ASA Special pub-lication. P. 65.

Shaver TM, Peterson GA, Ahuja LR, Westfall DG, Sherrod LA, Dunn G (2002). Surface soil physical properties after twelve years of dryland no-till management. Soil Sci. Soc. Am. J. 66(4):296-1303. http://dx.doi.org/10.2136/sssaj2002.1296

Singh RA (1980). Soil Physical Analysis," Kalyani Publishers, New 
Delhi, p. 165.

Savabi MR, Golabi MH, Abou-Arab AA, Kladivko EJ (2007). Infiltration characteristics of no-till vs conventional tillage in Indiana and Illinois farm fields. pp. 289-299. In T. Goddard et al. (ed.) No-till farming systems. Spec. Publ. 3. World Association of Soil and Water Conservation, Tokyo.

Sayre KD (2004). Raised Bed Cultivation. In: R.Lal, Ed., Encyclopedia of Soil Science, Marcel Dekker, Inc., New York.

Saharawat YS, Bhagat S, Malik RK, Ladha JK, Gathala MK, Jat ML, Kumar V (2010). Evaluation of Alternative Tillage and Crop Establishment Methods in a Rice-Wheat Rotation in North Western IGP. Field Crop Res. 116(3):260-267. http://dx.doi.org/10.1016/j.fcr.2010.01.003

Schjonning P, Rasmussen KJ (2000). Soil strength and soil pore characteristics for direct drilled and ploughed soils. Soil Tillage Res. 57(1-2):69-82. http://dx.doi.org/10.1016/S0167-1987(00)00149-5

Tanaka DL, Anderson RL (1997). Soil water storage and precipitation storage efficiency of conservation tillage systems. J. Soil Water Conserv. 52:363-367.
Unger PW, Cassel PK (1991). Tillage implement disturbance effects on soil properties related to soil and water conservation: A Literature Review. Soil Tillage Res. 19:363-382. http://dx.doi.org/10.1016/01671987(91)90113-C

Vez A (1979). Soil tillage in a long term wheat monoculture. In:Proceedings of the $8^{\text {th }}$ Conference on International Soil Tillage Research Organization,vol.2,Stuttgart,Hohenheim,Germany, pp. 263269.

Wuest SB, Williams JD, Gollany HT (2006). Tillage and perennial grass effects on ponded infiltration for seven semi-arid loess soils. J. Soil Water Conserv. 61(4):218-223.

Zadoks JC, Chang TT, Konzak CF (1974). A Decimal Code for the Growth Stages of Cereals. Weed Res. 14(6):415-42. http://dx.doi.org/10.1111/j.1365-3180.1974.tb01084.x 